\title{
GAMBARAN HISTOPATOLOGIK LAMBUNG TIKUS WISTAR YANG DIBERIKAN BUAH PEPAYA SEBELUM INDUKSI ASPIRIN
}

\author{
${ }^{1}$ Vallery Jerry Nanlohy \\ ${ }^{2}$ Carla Kairupan \\ ${ }^{2}$ Lily Loho
}

\author{
${ }^{1}$ Kandidat Skripsi Fakultas Kedokteran Universitas Sam Ratulangi Manado \\ ${ }^{2}$ Bagian Patologi Anatomi Fakultas Kedokteran Universitas Sam Ratulangi Manado \\ Email: vallery.nanlohy@yahoo.com
}

\begin{abstract}
Aspirin contains acetyl salicylic acid which can cause qualitative change on the gastric mucosa. The active ingredients of papaya can increase immunity and protect the stomach from the use of aspirin and steroid. Objective: To reveal the histophatological features of the stomach of Wistar rats administered with papaya juice before aspirin induction. Method: This experimental research employed 20 wistar rats which were divided into the negative control group (A) and treatment groups. All rats were fed with regular or standard pellets for 10 days. Treatment groups were classified into four groups; rats were given papaya juice of $0.8 \mathrm{cc} /$ day (group B), rats were administered aspirin of $30 \mathrm{mg} /$ day (group C), rats were given papaya juice $0.8 \mathrm{cc} /$ day before induced with aspirin (group D), and rats were given papaya juice $2.4 \mathrm{cc} /$ day before induced with aspirin of $30 \mathrm{mg}$ /day (group E). On the eleventh day, the rats were terminated to isolate the stomach followed by macroscopic and microscopic examinations. Results: It was found that the microscopic features were normal in negative control group and group B. In group C, histological examination showed acute gastritis, i.e.,inflammatory cells, edema mucosa and capillary dilatation. Rats in group D and E showed lower degree of acute gastritis compared with group C. Conclusions: Administration of papaya juice for 10 days before aspirin is given may reduce the signs of acute gastritis as demonstrated by histopathological features of the stomach of wistar rats. Administration of papaya juice of $2.4 \mathrm{cc} /$ day result in lower degree of gastritis compared with recommended dose of papaya juice ( $0.8 \mathrm{cc} /$ day).
\end{abstract}

Keywords: Aspirin, papaya, stomach.

\begin{abstract}
Abstrak: Aspirin mengandung asam asetil salisilat yang dapat menimbulkan perubahan kualitatif mukus lambung. Bahan aktif buah pepaya dapat meningkatkan kekebalan dan melindungi lambung dari penggunaan obat aspirin dan steroid. Tujuan: Untuk mengetahui gambaran histopatologik lambung tikus wistar yang diberikan jus buah pepaya sebelum induksi aspirin. Metode: Penelitian eksperimental ini menggunakan 20 ekor tikus wistar yang dibagi dalam kelompok kontrol negatif (A) dan kelompok perlakuan yang diberikan diet pellet standar selama 10 hari. Kelompok perlakuan dibagi dalam empat kelompok, yaitu kelompok yang diberikan jus pepaya 0,8 cc/hari (B), kelompok yang diberikan aspirin $30 \mathrm{mg} / \mathrm{hari}$ (C), kelompok yang diberikan jus pepaya 0,8 cc/hari sebelum diinduksi aspirin (D), dan kelompok yang diberikan jus pepaya 2,4 cc/ hari sebelum diinduksi aspirin $30 \mathrm{mg} /$ hari (E). Pada hari ke11 Tikus wistar diterminasi untuk diambil lambungnya yang kemudian diamati secara makroskopik dan mikroskopik. Hasil: Penelitian ini menunjukkan gambaran mikroskopik yang normal pada kelompok kontrol negatif dan perlakuan B. Pada kelompok perlakuan C menunjukkan gambaran histologik gastritis akut, yaitu sel-sel radang, edema mukosa, dan pelebaran kapiler. Pada kelompok perlakuan D dan E menunjukkan gambaran histologi gastritis akut yang lebih ringan dibandingkan dengan kelompok perlakuan C. Simpulan: Pemberian jus buah pepaya sebelum pemberian aspirin selama 10 hari dapat mengurangi
\end{abstract}


tanda-tanda gastritis akut yang terlihat pada gambaran histopatologik lambung tikus wistar. Pemberian jus buah pepaya sebanyak 2,4 cc/hari menghasilkan gambaran gastritis yang lebih ringan dibandingkan dengan pemberian dosis anjuran (0,8 cc/hari) jus buah pepaya.

Kata Kunci: Aspirin, pepaya, lambung.

Lambung merupakan salah satu dari organ gastrointestinal. Gangguan atau penyakit lambung berkisar dari gastritis akut hingga karsinoma lambung. ${ }^{1}$ Gangguan lambung memiliki gejala nyeri epigastrium yang samar dan rasa panas di dada. Salah satu penyebab dari gangguan lambung adalah pemberian obat antiinflamasi non-steroid (NSAID) terutama aspirin dalam jumlah besar. $^{2}$

Aspirin (asam asetil salisilat) adalah analgesik, anti piretik, dan antiinflamasi yang luas digunakan dan digolongkan dalam obat bebas. Pemberian aspirin dapat menimbulkan perubahan perubahan kualitatif mukus lambung sehingga mengakibatkan kerusakan jaringan terutama pembuluh darah. ${ }^{2}$ Efek penggunaan aspirin dapat dicegah dengan mengkonsumsi buah pepaya sebelumnya. ${ }^{3}$

Pepaya merupakan selah satu buah yang sangat dikenal oleh masyarakat Indonesia. Zat gizi dan nutrisi yang terkandung dalam buah pepaya yaitu betakaroten, betacryptoxanthin, protein, enzim papain, vitamin $\mathrm{C}$, serat, dan mineral. ${ }^{4}$ di Antara kandungan buah pepaya tersebut, papain yang paling banyak bermanfaat. Manfaat papain antara lain membantu melancarkan pencernaan, mengurangi radang lambung, dan mengurangi ketebalan ketebalan jaringan parut. ${ }^{3}$

Berdasarkan informasi mengenai khasiat buah pepaya tersebut maka dilakukan penelitian untuk membuktikan buah pepaya mampu melindungi lambung dari kerusakan yang diakibatkan oleh aspirin.

\section{METODE PENELITIAN}

Penelitian ini merupakan penelitian eksperimental laboratorik, dilakukan pada periode Oktober 2012-Januari 2013 di Laboratorium Patologi Anatomi Fakultas Kedokteran Universitas Sam Ratulangi
Manado. Penelitian menggunakan 20 ekor tikus wistar dewasa dengan berat rata-rata 200 gram, yang terdiri dari kelompok kontrol (A) dan kelompok perlakuan yang diberikan diet pellet standar selama 10 hari. Kelompok perlakuan dibagi dalam empat kelompok yaitu kelompok B yang diberikan jus buah pepaya $0,8 \mathrm{cc} / \mathrm{hari}$, kelompok $\mathrm{C}$ yang diberikan aspirin 30 mg/hari, kelompok D yang diberikan jus pepaya $0,8 \mathrm{cc} /$ hari sebelum diinduksi aspirin, dan kelompok E yang diberikan jus pepaya 2,4 cc/hari sebelum diinduksi aspirin. Kelima kelompok ini diterminasi dihari ke-11. Aspirin yang digunakan adalah aspirin bayer dengan berat 5 gram yang dibeli di apotik. Pepaya yang digunakan adalah pepaya mengkal yang sudah dihaluskan dengan blender, disaring, dan diambil jusnya. Pepaya dan aspirin diberikan pada hewan uji secara oral (nasogastric tube).

Di akhir penelitian ini hewan uji diterminasi untuk diambil lambungnya. Lambung tikus diamati secara makroskopik dan mikroskopik kemudian hasilnya disajikan dalam bentuk tabel dan gambar.

\section{HASIL PENELITIAN DAN BAHASAN}

\section{Tikus Wistar Kelompok Kontrol (A)}

Tikus wistar kelompok ini merupakan kontrol negatif yang hanya diberikan pellet standar selama 10 hari. Pada tikus wistar kelompok ini diperoleh gambaran histologik lambung yang normal. Lapisan mukosa, submukosa, muskularis, dan serosa dalam keadaan normal tanpa adanya sel-sel radang dan edema mukosa.

\section{Tikus Wistar Kelompok B}

Tikus wistar kelompok ini merupakan kelompok yang diberikan jus pepaya 0,8cc/hari selama 10 hari. Pada kelompok 
ini diperoleh gambaran histologik lambung yang normal. Lapisan mukosa, submukosa, muskularis, dan serosa dalam keadaan normal tanpa adanya sel radang dan edema mukosa.

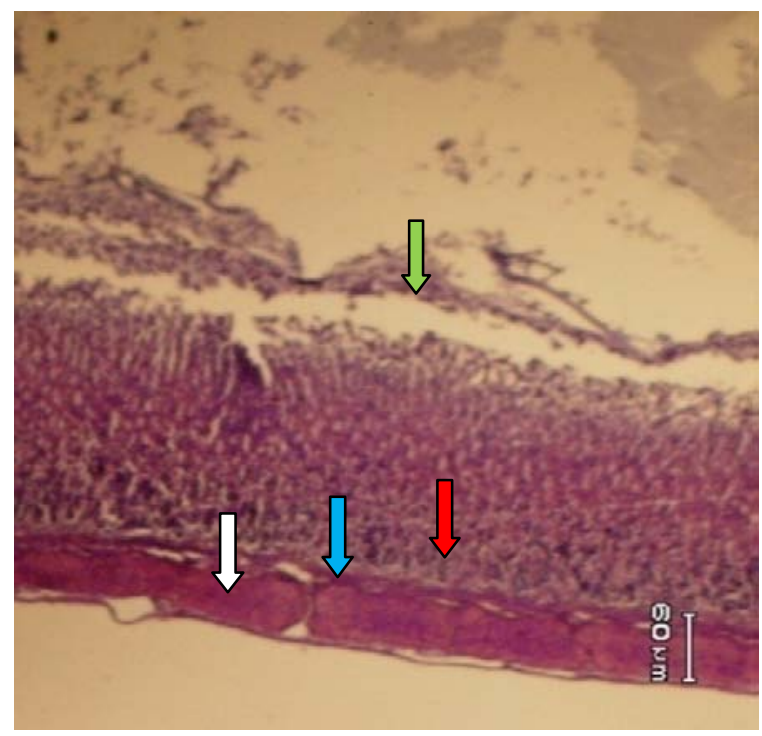

Gambar 1. Gambaran mikroskopik lambung tikus wistar kelompok A, pembesaran 4x10 (panah hijau: lapisan mukosa; panah merah: lapisan submukosa; panah biru: lapisan muskularis; panah putih: lapisan serosa).

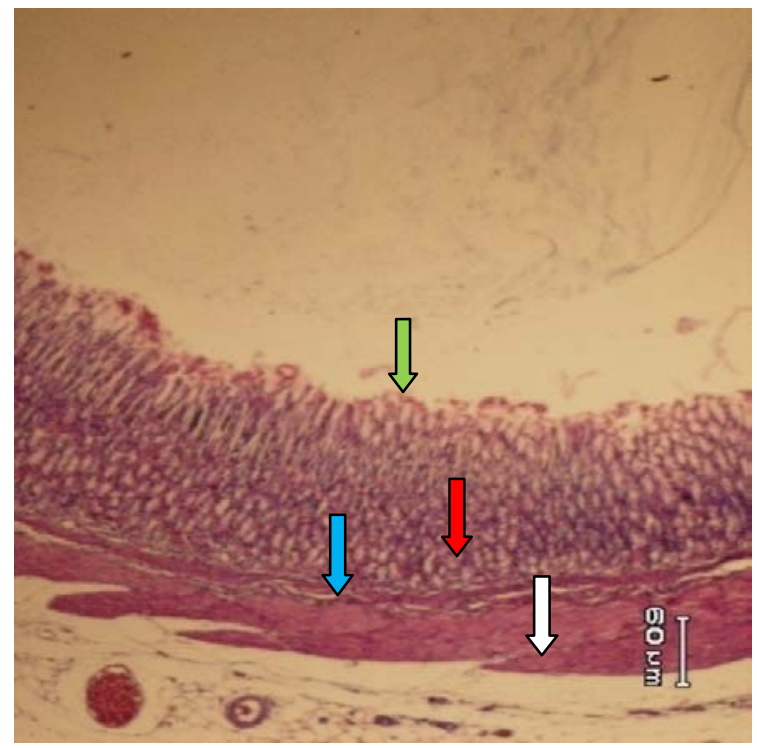

Gambar 2. Gambaran mikroskopik lambung tikus wistar kelompok B, pembesaran 4x10 (panah hijau: lapisan mukosa; panah merah: lapisan submukosa; panah biru: lapisan muskularis; panah putih: lapisan serosa).

\section{Tikus Wistar Kelompok C}

Tikus wistar kelompok ini merupakan kelompok yang diberikan obat aspirin dengan dosis $30 \mathrm{mg} /$ hari selama 10 hari. Pada kelompok ini diperoleh gambaran histologik yang memperlihatkan adanya sel-sel radang, edema,dan kapiler yang melebar.

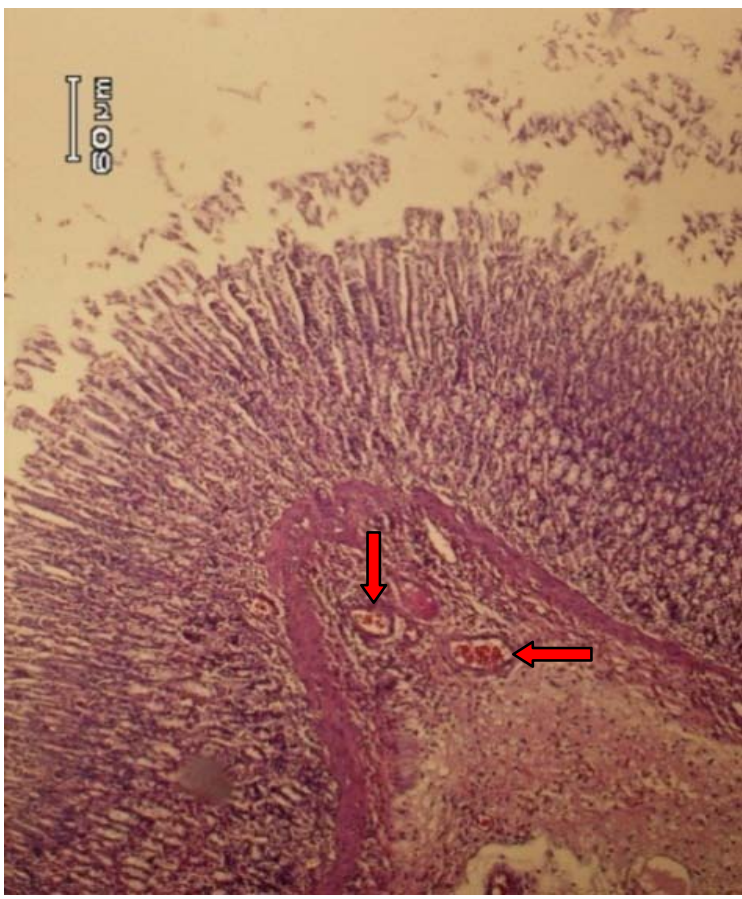

Gambar 3. Gambaran mikroskopik lambung tikus wistar kelompok C, pembesaran 4x10 dan 10x10 (panah merah: kapiler melebar; panah hijau: sel-sel radang).

\section{Tikus Wistar kelompok D}

Tikus wistar kelompok ini merupakan kelompok yang diberikan jus pepaya 0,8 cc/hari yang satu jam kemudian diinduksi aspirin dengan dosis $30 \mathrm{mg} / \mathrm{hari}$. Pada tikus wistar kelompok ini diperoleh gambaran histologik lambung yang memperlihatkan sel-sel radang, edema, dan kapiler yang melebar tetapi relatif lebih sedikit dibandingkan dengan yang terlihat pada kelompok C. Tikus wistar kelompok ini yang mati pada hari yang ketiga penelitian menunjukkan gambaran histologik lambung normal. 


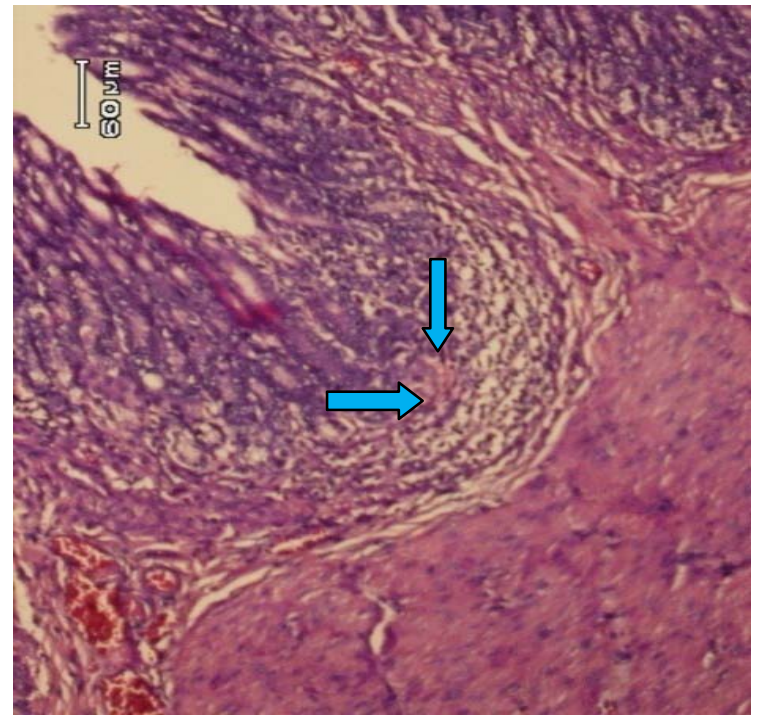

Gambar 4. Gambaran mikroskopik lambung tikus wistar kelompok D, pembesaran 10x10 (panah biru: Sel-sel radang).

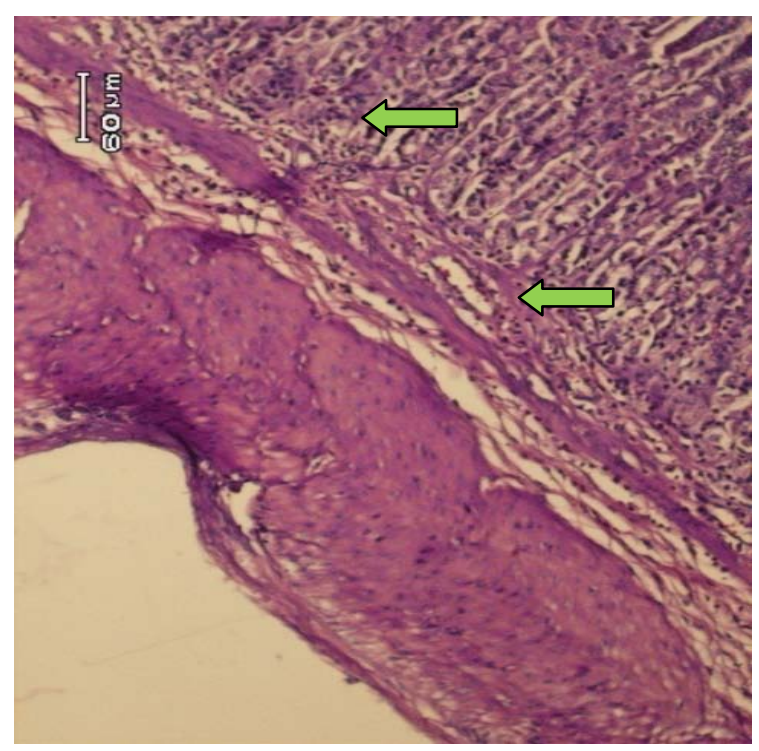

Gambar 5. Gambaran mikroskopik lambung tikus wistar kelompok E, pembesaran 10x10 (panah hijau: sel-sel radang).

\section{Hewan Uji Kelompok E}

Tikus wistar kelompok ini merupakan kelompok yang diberikan perlakuan jus pepaya 2,4 cc/hari yang satu jam kemudian diinduksi aspirin dengan dosis $30 \mathrm{mg} / \mathrm{hari}$ selama 10 hari. Pada tikus wistar kelompok ini diperoleh gambaran histologi lambung yang lebih baik dibandingkan yang terlihat pada kelompok $\mathrm{D}$, dimana terlihat sel-sel radang, edema, dan perdarahan mukosa yang lebih sedikit.

\section{BAHASAN}

Pepaya merupakan buah yang berkhasiat untuk menyempurnakan pencernaan dan dapat meningkatkan kekebalan tubuh. ${ }^{5}$ Aspirin merupakan salah satu dari golongan salisilat yang bersifat iritatif terhadap lambung. ${ }^{3}$ Penelitian ini memberikan data gambaran histopatologi lambung tikus wistar yang diberikan buah pepaya sebelum diinduksi dengan aspirin.

Tikus yang mendapatkan perlakuan 0,8 cc jus buah pepaya selama 10 hari dan tikus kelompok kontrol memiliki lambung dengan ciri yang sesuai dengan lambung normal. Sebaliknya, lambung tikus yang diberi aspirin $150 \mathrm{mg} / \mathrm{kgBB} /$ hari selama 10 hari memberikan gambaran peradangan akut (gastritis akut) berupa adanya sel-sel radang pada lapisan mukosa sampai serosa, edema mukosa, dan pelebaran kapiler. Peradangan tersebut merupakan efek samping dari penggunaan aspirin yaitu iritasi pada lambung yang disebabkan oleh sintesis prostaglandin terganggu. ${ }^{6}$ Terganggunya sintesis prostaglandin menyebabkan aliran darah pada daerah mukosa terganggu dan hilangnya lapisan mukus yang melindungi mukosa lambung. ${ }^{7}$

Pemberian jus buah pepaya sebelum diberikan aspirin ternyata dapat melindungi lambung dari efek negatif aspirin, seperti yang terlihat pada lambung tikus kelompok D ( jus buah pepaya $0,8 \mathrm{cc} /$ hari sebelum induksi aspirin) dan kelompok E ( jus buah pepaya 2,4 cc/hari sebelum induksi aspirin). Kedua kelompok tikus ini memiliki tanda-tanda gastritis akut yang lebih ringan dibandingkan dengan tikustikus yang tidak diberikan jus buah pepaya sebelum diinduksi aspirin.

Penelitian ini juga membuktikan bahwa jumlah jus buah pepaya yang lebih banyak (tiga kali lipat) memberikan efek lebih baik dalam menghambat kerusakan lambung (jus buah pepaya 0,8 cc 
dibandingkan dengan 2,4 cc). Papain yang terkandung dalam buah pepaya membantu pengaturan asam amino dan membantu mengeluarkan racun tubuh sehingga sistem kekebalan tubuh dapat ditingkatkan. ${ }^{8}$ Buah pepaya juga mengandung karoten dan vitamin $\mathrm{C}$ yang dapat meningkatkan antibodi. $^{9}$ Pemakaian obat aspirin berkepanjangan tetap harus dihindari karena buah pepaya tidak mampu melindungi sepenuhnya lambung secara sempurna dari efek samping penggunaan obat aspirin.

\section{SIMPULAN}

Berdasarkan hasil penelitian ini dapat disimpulkan bahwa pemberian jus buah pepaya sebelum pemberian aspirin selama 10 hari dapat mengurangi tanda-tanda gastritis akut berupa sel-sel radang, edema mukosa, dan kapiler melebar yang terlihat pada gambaran histopatologik lambung tikus wistar. Pemberian jus buah pepaya sebanyak 2,4 cc/hari menghasilkan gambaran gastritis yang lebih ringan terhadap lambung dibandingkan dengan pemberian dosis anjuran (0,8 cc/hari) jus buah pepaya.

\section{DAFTAR PUSTAKA}

1. Kumar V, Coltran RS, Robbins SL. Buku Ajar Patologi Volume 2 (Edisi Ketujuh). Jakarta: EGC, 2007; p.15, 622, 624-625.

2. Farmakologi dan terapi (Edisi Kelima). Jakarta: Departemen farmakologi dan terapeutik fakultas kedokteran universitas indonesia, 2007; 230-231, 234-237.

3. Dalimartha S, Adrian F. Khasiat buah dan sayur. Penebar Swadaya, 2011; p.67-9.

4. Yahya M. Khasiat daun pepaya untuk penderita kanker. Jakarta: Dunia Sehat, 2012; p.54, 57-9, 63-5.

5. Gemilang J. 1001 aneka buah \& sejuta khasiatnya ampuh mengatasi beragam penyakit. Yogyakarta: Araska, 2012; p.137140.

6. Nugroho AE. Farmakologi obat-obat penting dalam pembelajaran ilmu farmasi dan dunia kesehatan. Yogyakarta: Pusaka Pelajar, 2012; p.181-4.

7. Hariawang A. Gambaran histopatologi lambung tikus putih (Strain Wistar) setelah pemberian deksametason [Skripsi]. Manado: Fakultas Kedokteran Universitas Sam Ratulangi; 2008.

8. Prayoga A. Jurus sukses budidaya pepaya kalifornia. Abata press, 2011; P.8-9, 16-9, 23-5.

9. Hakimah IA. 81 macam buah berkhasiat istimewa. Jakarta: In Azna Books, 2012; p. 51-153. 